\title{
Evaluating long-term success in grassland restoration: an ecosystem multifunctionality approach
}

\author{
Monika Carol Resch (DD , ${ }^{1,7}$ Martin Schütz, ${ }^{1}$ Nina Buchmann (D), ${ }^{2}$ Beat Frey (iD), ${ }^{3}$ Ulrich Graf, ${ }^{4}$ \\ Wim H. van der Putten (iD,${ }^{5,6}$ Stephan Zimmermann (iD) ${ }^{3}$ and Anita C. Risch (iD 1 \\ ${ }^{1}$ Community Ecology, Swiss Federal Institute for Forest, Snow and Landscape Research (WSL), Birmensdorf 8903 Switzerland \\ ${ }^{2}$ Institute of Agricultural Sciences, Swiss Federal Institute of Technology (ETH) Zurich, Zurich 8092 Switzerland \\ ${ }^{3}$ Forest Soils and Biogeochemistry, Swiss Federal Institute for Forest, Snow and Landscape Research (WSL), \\ Birmensdorf 8903 Switzerland \\ ${ }^{4}$ Biodiversity and Conservation Biology, Swiss Federal Institute for Forest, Snow and Landscape Research (WSL), \\ Birmensdorf 8903 Switzerland \\ ${ }^{5}$ Department of Terrestrial Ecology, Netherland Institute of Ecology (NIOO-KNAW), Wageningen 6708 PB The Netherlands \\ ${ }^{6}$ Laboratory of Nematology, Wageningen University (WUR), Wageningen 6700 ES The Netherlands
}

Citation: Resch, M. C., M. Schütz, N. Buchmann, B. Frey, U. Graf, W. H. van der Putten, S. Zimmermann, and A. C. Risch. 2021. Evaluating long-term success in grassland restoration: an ecosystem multifunctionality approach. Ecological Applications 31(3):e02271. 10.1002/eap.2271

Abstract. It is generally assumed that restoring biodiversity will enhance diversity and ecosystem functioning. However, to date, it has rarely been evaluated whether and how restoration efforts manage to rebuild biodiversity and multiple ecosystem functions (ecosystem multifunctionality) simultaneously. Here, we quantified how three restoration methods of increasing intervention intensity (harvest only $<$ topsoil removal $<$ topsoil removal + propagule addition) affected grassland ecosystem multifunctionality $22 \mathrm{yr}$ after the restoration event. We compared restored with intensively managed and targeted seminatural grasslands based on 13 biotic and abiotic, above- and belowground properties. We found that all three restoration methods improved ecosystem multifunctionality compared to intensively managed grasslands and developed toward the targeted seminatural grasslands. However, whereas higher levels of intervention intensity reached ecosystem multifunctionality of targeted seminatural grasslands after $22 \mathrm{yr}$, lower intervention missed this target. Moreover, we found that topsoil removal with and without seed addition accelerated the recovery of biotic and aboveground properties, and we found no negative long-term effects on abiotic or belowground properties despite removing the top layer of the soil. We also evaluated which ecosystem properties were the best indicators for restoration success in terms of accuracy and cost efficiency. Overall, we demonstrated that low-cost measures explained relatively more variation of ecosystem multifunctionality compared to high-cost measures. Plant species richness was the most accurate individual property in describing ecosystem multifunctionality, as it accounted for $54 \%$ of ecosystem multifunctionality at only $4 \%$ of the costs of our comprehensive multifunctionality approach. Plant species richness is the property that typically is used in restoration monitoring by conservation agencies. Vegetation structure, soil carbon storage and water-holding capacity together explained $70 \%$ of ecosystem multifunctionality at only twice the costs $(8 \%)$ of plant species richness, which is, in our opinion, worth considering in future restoration monitoring projects. Hence, our findings provide a guideline for land managers how they could obtain an accurate estimate of aboveground-belowground ecosystem multifunctionality and restoration success in a highly cost-efficient way.

Key words: aboveground-belowground properties; biotic-abiotic properties; cost efficiency; long-term monitoring; nature management techniques; seminatural grasslands.

\section{INTRODUCTION}

Seminatural grasslands are an integral part of the Western and Central European cultural landscape and result from traditional farming over centuries (Van Dijk

Manuscript received 20 May 2020; revised 4 September 2020; accepted 5 October 2020. Corresponding Editor: Drew A. Scott.

${ }^{7}$ E-mail: carol.resch@wsl.ch
1991, Poschlod and Wallis De Vries 2002, Bobbink et al. 2011). These grasslands are among the most species-rich ecosystems and represent biodiversity hotspots that harbor specialized plant and animal communities with high numbers of rare and endangered species (Dengler et al. 2014). Seminatural grasslands are characterized by low productivity and high structural heterogeneity with a diverse mosaic of ecological niches and microhabitats (Diacon-Bolli et al. 2012). They are found on oligo- to mesotrophic soils that are sensitive to eutrophication 
(Bobbink et al. 1998, Bobbink et al. 2011). Maintaining these grasslands requires low-input agricultural management to prevent accumulation of soil nutrients and to impede reforestation (Poschlod and Wallis De Vries 2002). Seminatural grasslands also provide numerous ecosystem functions and services. For example, by supporting high abundance and diversity of invertebrates, they may provide pollination and pest control services for surrounding agricultural areas (Byrne and delBarcoTrillo 2019). They can be important for soil and water protection against pollution (Peciña et al. 2019) and may act as hydrological buffers (Gimmi et al. 2011). Seminatural grasslands were also found to mitigate droughts or floods and reduce carbon dioxide emissions due to their enhanced carbon storage capacities compared to arable land (Peciña et al. 2019). However, seminatural grasslands are under multiple pressures.

Since the late $19^{\text {th }}$ century, seminatural grasslands have been drastically reduced in their extent and connectivity (Wallis De Vries et al. 2002) as their low productivity made them prime for conversion into more profitable high-input agricultural land, or on the contrary, for complete abandonment (Quétier et al. 2007, Török and Dengler 2018). In Switzerland, for example, 95\% of seminatural grasslands were lost during the course of the past century (Lachat et al. 2010). As a consequence, efforts to protect the remaining areas were greatly enhanced, but their ongoing loss could not be stopped (Gattlen et al. 2017). Today, these grasslands represent species-rich islands in a landscape dominated by intensive agriculture. It became evident that sustainable conservation has to integrate restoration to actively extend and reconnect these fragmented remnants and to re-enable metapopulation dynamics and genetic exchange of biotic communities among the isolated patches (Lachat et al. 2010). Hence, converting adjacent intensively managed grasslands into seminatural grasslands became the focus of restoration projects (Kardol and Wardle 2010, Kiehl et al. 2010). Intensively managed grassland generally represents a highly eutrophic and homogenized habitat, dominated by only a few competitive generalist species while habitat specialists are scarce (De Deyn et al. 2003, Kardol and Wardle 2010). Thus, successful conversion of such intensively managed grasslands into nutrient-poor and species-rich communities relies on overcoming their agricultural legacy, which is preserved in overabundant soil nutrients as well as poor species and propagule availability (Bakker and Berendse 1999, McLauchlan 2006, Brinkman et al. 2017).

Various restoration strategies have been tested over the past decades. They affect above- and belowground, biotic and abiotic properties differently depending on their intervention intensity (e.g., Marrs et al. 1998, Kiehl and Pfadenhauer 2007, Kardol et al. 2008, Frouz et al. 2009, Suding 2011). Mild interventions, such as cessation of fertilization and multiple plant biomass harvests, have been rarely successful in lowering the high availability of soil nutrients and reestablishing targeted plant communities. Conversely, more severe interventions, such as topsoil removal with and without seed addition, were found to be highly successful in restoring oligotrophic grassland ecosystems (see review in Kiehl et al. 2010). However, removal of the nutrient-rich topsoil, typically a layer of $20-50 \mathrm{~cm}$, substantially affects belowground biota and abiotic soil conditions, and is therefore viewed rather critically (see Geissen et al. 2013).

Yet, to evaluate restoration success, usually only a few aboveground biotic properties, typically plant community composition, sometimes the presence/absence of selected insect species or taxa (e.g., grasshoppers, beetles) are used (e.g., Patzelt et al. 2001, Kardol et al. 2005, Kiehl and Wagner 2006, Kiehl and Pfadenhauer 2007, Klimkowska et al. 2007, Verhagen et al. 2008, Neff et al. 2020). More exhaustive evaluations are lacking and only few studies assessed belowground community composition and soil properties to determine restoration success (e.g., Frouz et al. 2009, Kardol et al. 2009b, Wubs et al. 2016, Resch et al. 2019). As restoration methods should enhance and reestablish biodiversity and ecosystem functioning both above- and belowground, success should be evaluated based on a comprehensive assessment of biotic and abiotic, above- and belowground properties, such as taxonomic and structural diversity, and soil functions and processes (Havlicek 2012, Greiner et al. 2018, Gann et al. 2019). Thus, a multifunctional approach could be highly suitable to validate successful reestablishment of the targeted species or ecosystem properties and functions over time (see review in Manning et al. 2018, but also see Meyer et al. 2015, Costantini et al. 2016).

In the present study, we assessed how three restoration methods of different intervention intensities, i.e., Harvest only (biomass removal), Topsoil (topsoil removal), and Topsoil + Propagules (topsoil removal plus addition of target plant species), succeeded in restoring ecosystem multifunctionality. We included 13 properties, namely aboveground arthropod richness, belowground faunal and microbial taxon richness, plant species richness, vegetation structure, above- and belowground functional diversity and food-web complexity, soil heterogeneity, soil carbon $(\mathrm{C})$ storage, water-holding capacity, nutrient retention capacity and soil net nitrogen $(\mathrm{N})$ mineralization in our ecosystem multifunctionality metric. Restoration success was compared to both intensively managed grasslands (Initial state) and ancient seminatural grasslands (Target state). The evaluation took place $22 \mathrm{yr}$ after restoration methods were implemented. To our knowledge, this is the first long-term study that combined aboveground and belowground ecosystem multifunctionality to evaluate the recovery of targeted ecosystem properties after grassland restoration. As measuring and assessing various ecosystem properties is cost-intensive, we conducted a "cost-benefit analysis" to determine which and how many ecosystem properties are needed to define ecosystem multifunctionality in 
restored grasslands as accurately as possible, but at affordable costs (effort, infrastructure, expert knowledge). This analysis should help environmental agencies that supervise restoration programs in their decisionmaking process. Overall, we aimed to answer the following research questions: (1) Does multifunctionality differ between intensively managed and seminatural grasslands? (2) Are the different restoration methods successful in restoring grassland multifunctionality? (3) How much do biotic and abiotic, above- and belowground properties contribute to ecosystem multifunctionality? (4) Which ecosystem properties are the best indicators to accurately describe multifunctionality in restored grasslands in a cost-effective way?

\section{Material AND Methods}

\section{Study area}

The study was conducted in the Canton of Zurich, Switzerland, in and around two nature reserves Eigental and Altläufe der Glatt $\left(47^{\circ} 27^{\prime}\right.$ to $47^{\circ} 29^{\prime} \mathrm{N}, 8^{\circ} 37^{\prime}$ to $8^{\circ} 32^{\prime} \mathrm{E}, 417$ to $572 \mathrm{~m}$ above sea level). All studied grasslands were located with a radius of approximately $4 \mathrm{~km}$. Average monthly temperatures range from $0.7^{\circ} \pm 2.0^{\circ} \mathrm{C}$ (January) to $19.0^{\circ} \pm 1.5^{\circ} \mathrm{C}$ (July), and monthly precipitation range from $60 \pm 42 \mathrm{~mm}$ (January) to $118 \pm 46$ mm (July [maxima]; 1987-2017; MeteoSchweiz 2018). The two nature reserves contain small-scale grassland mosaics differing in their nutrient and water availability. In our study, we focused on semi-dry and semi-wet oligo- to mesotrophic grasslands characterized by high plant species richness and groundwater fluctuations throughout the year (Delarze et al. 2015, see also Resch et al. 2019).

\section{Experimental design and sampling}

A large-scale restoration experiment to expand and reconnect isolated remnants of species-rich grasslands was initiated in the nature reserve Eigental in 1990. Twenty hectares of adjacent intensive grasslands were chosen for restoration. In 1995, three restoration methods of increasing intervention intensities were implemented. The goal of all three methods was to lower the availability of soil nutrients and hence, facilitate ecosystem development toward the targeted nutrient-poor grasslands. These methods were Harvest only (hay harvest twice a year), Topsoil (removal of the nutrient-rich topsoil), and Topsoil + Propagules (topsoil removal combined with the application of hay from target vegetation; further details see Resch et al. 2019). Plant biomass harvest (once a year in late summer/early autumn) commenced in Topsoil and Topsoil + Propagules five years after the soils were removed and is still ongoing today (see Appendix S1: Table S1). We measured restoration success by comparing the three restoration methods with intensively managed (Initial) and seminatural grasslands
(Target) $22 \mathrm{yr}$ after restoration. Initial grassland sites share the same agricultural history as the restored sites: mowing and subsequent fertilizing (manure) up to five times a year, as well as different tillage regimes (see Appendix S1: Table S1; Resch et al. 2019). Target sites were the sites from which hay for seeding the Topsoil + Propagules sites was collected. Soil conditions (i.e., soil types, soil texture) were comparable to those found in the restored grasslands (see Appendix S1: Table S1; Resch et al. 2019). Additionally, Target sites were selected to represent a variety of seminatural grasslands, including semi-dry to semi-wet conditions. In Target grasslands, biomass is harvested once a year in late summer or early autumn. Eleven $5 \times 5 \mathrm{~m}\left(25 \mathrm{~m}^{2}\right)$ plots were randomly established in each of the five treatments (in total 55 plots; for a detailed map see Neff et al. 2020). An additional $2 \times 2 \mathrm{~m}\left(4 \mathrm{~m}^{2}\right)$ subplot was randomly established at least $2 \mathrm{~m}$ away from each $25-\mathrm{m}^{2}$ plot for destructive sampling. Data sampling took place between June and September 2017.

Vegetation properties. - All plant species were identified within the $25-\mathrm{m}^{2}$ plots (nomenclature: Lauber and Wagner 1996) in mid-June 2017 (in total 250 species). Vegetation structure and plant biomass were assessed diagonally on a transect of $2 \mathrm{~m} \times 10 \mathrm{~cm}$ within the 25 $\mathrm{m}^{2}$ plot in early July 2017. We measured the maximum and mean height of the vegetation at the start, middle, and end of the transect and calculated the standard deviation of these measures to describe vegetation structural heterogeneity (Schuldt et al. 2019). Thereafter, biomass was clipped on the entire transect to $1 \mathrm{~cm}$ height, sorted into five functional groups (graminoids, forbs, legumes, litter, and woody species; see Data availability, dried at $60^{\circ} \mathrm{C}$ for $48 \mathrm{~h}$, and weighed (Meyer et al. 2015).

Aboveground arthropods.-Aboveground arthropods were sampled at two locations in each $25-\mathrm{m}^{2}$ plot in early July 2017 (see also Neff et al. 2020). Briefly, two cylindrical baskets (50 cm diameter, $67 \mathrm{~cm}$ height; woven fabric) were thrown simultaneously from outside the plot into two opposite corners. A closable mosquito mesh sleeve was mounted to the top of the baskets and an integrated metal ring at the bottom was fixed to the ground with metal stakes to assure that insects could not escape. A suction sampler (Vortis, Burkard Manufacturing, Hertfordshire, UK) was then inserted into one of the baskets through the opening of the sleeve and the plot was "vacuumed" twice for $105 \mathrm{~s}$ with a 30 -s break. The collected animals were immediately transferred into $70 \%$ ethanol. Arthropods were sorted and assigned to 23 taxonomic groups (Appendix S1: Table S3; see Data availability). Holometabolic larvae were lumped into one category while hemimetabolic larvae were grouped separately from adults in the respective taxonomic rank. We used mean values of individuals per plot for total abundance. Aboveground arthropod richness was defined by the number of different taxa to lowest taxonomic level (in 
total 23 taxa). All taxa were assigned to one of five trophic levels: (1) primary producers, (2) primary consumers, (3) secondary consumers, (4) tertiary consumers, and (5) quaternary consumers (Appendix S1: Table S3).

Belowground fauna.-Sampling of all belowground fauna took place in mid-July 2017. Earthworms were sampled in two $30 \mathrm{~cm} \times 30 \mathrm{~cm} \times 20 \mathrm{~cm}$ soil monoliths at two opposite corners of the $25-\mathrm{m}^{2}$ plot (opposite to aboveground arthropod sampling). The excavated soil monolith was broken by hand, all earthworms collected and immediately transferred in a $4 \%$ formaldehyde solution. Thereafter, earthworm individuals were identified to species level (in total 10 taxa; Christian and Zicsi 1999) and species assigned to three functional groups (Appendix S1: Table S3; see Data availability; Bouché 1977).

To assess soil arthropod communities, we randomly collected one undisturbed soil core $(5 \mathrm{~cm}$ diameter, $12 \mathrm{~cm}$ depth) in each 4- $\mathrm{m}^{2}$ subplot with a slide hammer corer lined with a plastic sleeve (AMS Samplers, American Falls, Idaho, USA). Soil arthropods were extracted using Berlese-Tullgren funnels ( $3 \mathrm{~mm}$ mesh), starting the day of sampling and lasting $14 \mathrm{~d}$. Individuals were stored in $70 \%$ ethanol. Soil arthropods were assigned to 41 taxonomic groups and 4 feeding types (Appendix S1: Table S3; see Data availability). Holometabolic and hemimetabolic larvae were treated as previously described for aboveground arthropods. Belowground arthropod richness refers to the 41 taxonomic groups.

For soil nematode sampling, we randomly collected eight soil cores of $2.2 \mathrm{~cm}$ diameter (Giddings Machine Company, Windsor, Colorado, USA) within each $4-\mathrm{m}^{2}$ subplot to a depth of $12 \mathrm{~cm}$. The eight cores were combined, gently homogenized, placed in coolers, kept at $4^{\circ} \mathrm{C}$ and transported to the laboratory at NIOO in Wageningen (Netherlands) within one week after collection. Free-living nematodes were extracted from $200 \mathrm{~g}$ of fresh soil using Oostenbrink elutriator (Oostenbrink 1960 ) and prepared for morphological identification and quantification as described by Resch et al. (2019). Nematodes were identified to family level (39 taxa) according to Bongers (1988), assigned to 17 functional groups, 5 feeding types, and 5 colonizer-persister (C-P) classes (Appendix S1: Table S3; see Data availability; Yeates et al. 1993, Bongers 1990, Resch et al. 2019).

We randomly collected two more soil cores $(2.2 \mathrm{~cm}$ diameter $\times 12 \mathrm{~cm}$ depth) within each $4-\mathrm{m}^{2}$ subplot to determine soil microbial communities. Again, the soil cores were combined, homogenized, placed in coolers and transported to the laboratory at WSL in Birmensdorf (Switzerland) where the metagenomic DNA was extracted from $8 \mathrm{~g}$ sieved soil $(2 \mathrm{~mm})$ using the DNeasy PowerMax Soil Kit (Qiagen, Hilden, NRW, Germany) according to the manufacturer's instructions. PCR amplification of the V3-V4 region of the prokaryotic small-subunit (16S) and the ribosomal internal transcribed spacer region (ITS2) of eukaryotes was performed with $1 \mathrm{ng}$ of template DNA utilizing PCR primers and conditions as previously described (Frey et al. 2016). PCRs were run in triplicates and pooled. The pooled amplicons were sent to the Genome Quebec Innovation Centre (Montreal, Quebec, Canada) for barcoding using the Fluidigm Access Array technology (Fluidigm) and paired-end sequencing on the Illumina MiSeq v3 platform (Illumina, San Diego, California, USA). Quality filtering, clustering into operational taxonomic units (OTUs) and taxonomic assignment were performed as described by Frey et al. (2016) and Adamczyk et al. (2019). We used a customized pipeline largely based on UPARSE (Edgar 2013) implemented in USEARCH v. 9.2 (Edgar 2010). After discarding singletons of dereplicated sequences, clustering into OTUs with 97\% sequence similarity was performed (Edgar 2013). Quality-filtered reads were mapped on the filtered set of centroid sequences. Taxonomic classification of prokaryotic and fungal sequences was conducted querying against most recent versions of SILVA (v.132; Quast et al. 2013) and UNITE (v.8; Nilsson et al. 2018). Only taxonomic assignments with confidence rankings equal or higher than 0.8 were accepted (assignments below 0.8 set to unclassified). Prokaryotic OTUs assigned to mitochondria or chloroplasts as well as eukaryotic OTUs assigned other than fungi were removed prior to data analysis. In addition, prokaryotic and fungal data sets were filtered to discard singletons and doubletons. Thereafter, OTU abundance matrices were rarefied to the lowest number of sequences per community, to normalize the total number of reads and achieve parity between samples (Prokaryota: 29,843 reads; Fungi: 26,690 reads). Finally, prokaryotic and fungal observed richness (number of OTUs) were estimated (Prokaryota: 14,010 OTUs; Fungi: 5,813 OTUs). For prokaryotes, we distinguished five and for fungi six functional types based on lowest taxonomic resolution (Appendix S1: Table S3; see Data availability; Nguyen et al. 2016, Tedersoo et al. 2014). Belowground taxon richness was defined by the total number of earthworm, arthropod, nematode, fungi, and prokaryote taxa assigned to lowest taxonomic level. Finally, all belowground taxa were assigned to the same five trophic levels as the aboveground arthropods (Appendix S1: Table S3; see Data availability).

Soil chemical and physical properties, soil nitrogen mineralization.-We randomly collected three $5 \mathrm{~cm}$ diameter $\times 12 \mathrm{~cm}$ depth soil samples in each $4-\mathrm{m}^{2}$ subplot with a slide hammer corer (AMS Samplers, American Falls, Idaho, USA), pooled them and then made two subsamples. One was field fresh and stored at $3^{\circ} \mathrm{C}$ until analysis, the other was dried for $48 \mathrm{~h}$ at $60^{\circ} \mathrm{C}$ and passed through a 4-mm mesh. From the dried sample, we measured soil $\mathrm{pH}$ potentiometrically in $0.01 \mathrm{~mol} / \mathrm{L} \mathrm{CaCl}$ (soil : solution ratio $=1: 2 ; 30$-minute equilibration time). Total and organic carbon content were measured on fine-ground samples $(\leq 0.5 \mathrm{~mm})$ by dry combustion 
using a CN analyzer NC 2500 (CE Instruments, Wigan, $\mathrm{UK})$. Inorganic carbon of samples with a $\mathrm{pH}>6.5$ was removed with acid vapor prior to analysis of organic carbon (Walthert et al. 2010). We calculated total soil carbon (C) storage after correcting its content for soil depth, stone content, and density of fine earth. Exchangeable cations were determined on another $5 \mathrm{~g}$ dry soil sample with $50 \mathrm{~mL}$ unbuffered $1 \mathrm{~mol} / \mathrm{L} \mathrm{NH}_{4} \mathrm{Cl}$ solution (soil : solution ratio $=1: 10$, end-over-end shaker for $1.5 \mathrm{~h}$ ) and measured by an ICP-OES (Optima 7300 DV, Perkin-Elmer, Waltham, Massachusetts, USA). Thereafter, cation exchange capacity (CEC) was calculated as the sum of exchangeable cations and protons (and expressed as $\mathrm{mmol}_{\mathrm{c}}$ per $1 \mathrm{~kg}$ soil) and used to describe nutrient retention capacity in our plots. Concentrations of exchangeable protons were calculated as the difference between total and Al-induced exchangeable acidity as determined by the $\mathrm{KCl}$-method (Thomas 1982).

Ammonium $\left(\mathrm{NH}_{4}^{+}\right)$and nitrate $\left(\mathrm{NO}_{3}^{-}\right)$were extracted from a $20 \mathrm{~g}$ fresh subsample with $80 \mathrm{~mL} 1 \mathrm{~mol} / \mathrm{L} \mathrm{KCl}$ for $1.5 \mathrm{~h}$ on an end-over-end shaker and filtered through ashless folded filter paper (DF 5895 150, ALBET LabScience, Hahnemühle FineArt GmbH, Dassel, Germany). concentrations were determined colorimetrically by automated flow injection analysis (FIAS 300, PerkinElmer, Waltham, Massachusetts, USA). $\mathrm{NO}_{3}^{-}$concentrations were measured colorimetrically according to Norman and Stucki (1981). Potential soil net nitrogen (N) mineralization was assessed during an 8-week incubation period under controlled moisture $(60 \%$ of field capacity), temperature $\left(20^{\circ} \mathrm{C}\right)$ and light conditions (dark) in the laboratory. We weighed duplicate samples of fresh soil equivalent to $8 \mathrm{~g}$ dry soil $\left(24 \mathrm{~h}\right.$ at $\left.104^{\circ} \mathrm{C}\right)$ into 50-mL Falcon tubes. Soil samples were extracted for $\mathrm{NH}_{4}^{+}$and $\mathrm{NO}_{3}^{-}$at the beginning and after eight weeks as previously described. Soil net $\mathrm{N}$ mineralization was calculated as the difference between the inorganic nitrogen $\left(\mathrm{NH}_{4}^{+}\right.$and $\left.\mathrm{NO}_{3}^{-}\right)$before and after the incubation (Hart et al. 1994), corrected for the total incubation time and represented per day values expressed as mg $\mathrm{N} \cdot \mathrm{kg}$ soil $^{-1} \cdot \mathrm{d}^{-1}$.

To assess soil physical properties, we randomly collected one undisturbed soil core per 4- $\mathrm{m}^{2}$ subplot $(5 \mathrm{~cm}$ diameter, $12 \mathrm{~cm}$ depth) in a steel cylinder that fit into the slide hammer (AMS Samplers, American Falls, Idaho, USA). The cylinder was capped in the field to avoid disturbance. We then measured field capacity in the laboratory. For this purpose, the cylinder and soil therein were saturated in a water bath and drained on a sand/silt-bed with a suction corresponding to $60 \mathrm{~cm}$ hydrostatic head. The moist soil was dried at $105^{\circ} \mathrm{C}$ to constant mass. Field capacity was calculated by dividing the mass of water by the total mass of wet soil contained at $60-\mathrm{cm}$ hydrostatic head and used to describe waterholding capacity. Thereafter, samples were passed through a 4-mm mesh. Fine-earth and skeleton fractions were weighed separately to assess bulk soil density (fine- earth plus skeleton), density of fine earth, and proportion of skeleton. Particle density was determined with the pycnometer method (Blake and Hartge 1986), and total porosity and proportion of fine pores were calculated (Danielson and Sutherland 1986). Clay, silt, and sand contents were quantified with the sediment method (Gee and Bauder 1986).

Surface and soil temperature $(12 \mathrm{~cm}$ depth, water-resistant digital pocket thermometer; IP65, H-B Instrument, Trappe, Pennsylvania, USA) as well as volumetric soil moisture content $(12 \mathrm{~cm}$ depth, time domain reflectometry; Field-Scout TDR 300, Spectrum Technologies, Aurora, Illinois, USA) were measured at five random locations within the 4- $\mathrm{m}^{2}$ subplots every month from June to September. We calculated the standard deviation of each temperature and moisture measure over four months to describe seasonal variations. Slope inclination was determined at plot level via GPS measurements (GPS 1200, Leica Geosystem, Heerbrugg, Switzerland) and categorized into slope gradient classes according to FAO standards (1990). Thickness of the topsoil horizon (equivalent to $\mathrm{Ah}$ or Aa horizon) was determined at one soil monolith $\left(30 \times 30 \times 30 \mathrm{~cm}^{3}\right)$ per $4-\mathrm{m}^{2}$ subplot in centimeters and rounded to next integer.

\section{Ecosystem properties and multifunctionality (Research question 1-3)}

In total, we used 13 ecosystem properties that represented four major ecosystem attributes, namely biodiversity (plant species richness, aboveground arthropod richness, belowground taxon richness), structural diversity (vegetation structure, soil heterogeneity, above- and belowground functional diversity, above- and belowground food-web complexity), soil functions (soil C storage, water-holding capacity, nutrient retention capacity), and soil processes (soil net $\mathrm{N}$ mineralization; Appendix S1: Table S2).

Selection of the 13 properties was based on suggested international principles and standards on ecological restoration of the Society for Ecological Restoration (SER), and thus, included standardized indicators of restoration success (McDonald et al. 2016, Gann et al. 2019). We used individual properties that were shown to increase ecosystem functioning and invasion resistance, i.e., ecosystem stability, two major goals in ecological restoration (details on rationales see Appendix S1: Table S2). Thus, we assumed that restoring these properties and increasing their values is mandatory to meet the primary objective of a restoration project, namely restoring high levels of ecosystem functioning and strengthening of ecosystem stability (Gann et al. 2019).

Soil heterogeneity was calculated based on 20 soil properties (soil $\mathrm{pH}$, organic $\mathrm{C}$ content, $\mathrm{NO}_{3}^{-}$and $\mathrm{NH}_{4}^{+}$ concentrations, concentrations of exchangeable cations [Ca, $\mathrm{K}, \mathrm{Mg}, \mathrm{Na}, \mathrm{Mn}]$, bulk density, texture, proportion of skeleton and fine pores, thickness of topsoil horizon, slope class, seasonal variation in surface and soil 
temperature as well as soil moisture). We $z$-transformed the 20 properties and then calculated multivariate Euclidean distances for all pairwise between- and withingroup combinations for each treatment. We then used differences in group homogeneities based on group dispersion variances, i.e., distance of single plot to its corresponding group centroid to obtain soil heterogeneity (betadisper function of the vegan package; Alsterberg et al. 2017, Oksanen et al. 2019).

We calculated functional diversity for plants using shoot biomass of plant functional groups and for faunal and microbial communities by assigning all taxonomic levels to functional groups. In total, 46 functional groups were defined based on lowest taxonomic resolution for each biotic community (see Appendix S1: Table S3; see Data availability). We calculated multivariate Euclidean distances on $z$-transformed functional groups (relative abundances) for all pairwise combinations of treatments and defined functional diversity above- and belowground using differences in group homogeneities based on group dispersion variances.

Food-web complexity for faunal and microbial functional groups was based on life-history traits. For each functional group, we assigned (1) feeding type, (2) trophic level, and (3) sensitivity to stress and/or disturbance and recolonization ability (SD level), based on well-established bioindicative methods (Bongers 1990, Parisi et al. 2005). For this study, we extended these methods to also address aboveground arthropods, earthworms, prokaryotes, and fungi. The ecomorphological index concept of soil microarthropods (Parisi et al. 2005) was adopted for aboveground arthropods. For earthworms, we ranked the sensitivity according to the $r$ - and $K$-strategy (Römbke et al. 2005): sensitivity was ranked lowest for epigeic species (1), followed by endogeic (5), and highest for anecic species (9). The prokaryotic community was classified based on copiotrophicoligotrophic characteristic (for a review, see Ho et al. 2017): copiotrophic and undefined bacteria received lowest (1), oligotrophic bacteria highest (9) rank. The fungal community was ranked based on the copiotrophic-oligotrophic concept only if known (for a review, also see Ho et al. 2017): copiotrophic saprotrophs, pathotrophs (excluding animal), and undefined fungi were ranked lowest (1); symbiotrophs, biotrophs, animal pathogens, and oligotrophic saprotrophs received the highest ranking (9); saprotrophs (excluding oligo- or copiotrophs) and others received an intermediate ranking (5). We then defined the trait-based factor as follows: (1) the digit before the comma was defined by the feeding type and trophic level (ranging from 1 to 5), (2) the digit after the comma corresponded to stress/disturbance sensitivity and recolonization ability (ranging from 1 to 9). Higher values of the trait-based factor indicated higher food-web complexity (see Appendix S1: Table S3). We calculated weighted abundance per functional group by multiplying relative abundance per functional group with its corresponding trait-based factor. Thereafter, food-web complexity was defined as the standardized community weighted mean for the above- and belowground communities separately.

We calculated five different multifunctionality measures using the averaging approach (Hooper and Vitousek 1998). Ecosystem multifunctionality included all 13 ecosystem properties. We also calculated aboveground multifunctionality (plant richness and vegetation structure, aboveground arthropod richness, functional diversity, food-web complexity), belowground multifunctionality (belowground taxon richness, functional diversity, food-web complexity, soil heterogeneity, soil C storage, water-holding capacity, nutrient retention capacity, soil net $\mathrm{N}$ mineralization), biotic multifunctionality (aboveground arthropod richness, belowground taxon richness, plant richness, vegetation structure, above- and belowground functional diversity, food-web complexity), and abiotic multifunctionality (soil heterogeneity, soil C storage, water-holding capacity, nutrient retention capacity, and soil net $\mathrm{N}$ mineralization). We did not use the threshold approach (Gamfeldt et al. 2008), as we were not interested in assessing the number of properties performing above a certain threshold, but in comparing levels of multifunctionality in restored systems with those of our targeted seminatural grasslands. The availability of a real-world target rather than any arbitrarily chosen threshold justifies the use of the averaging approach (Byrnes et al. 2014, Gamfeldt and Roger 2017).

All five multifunctionality measures were calculated after standardizing each ecosystem property (DelgadoBaquerizo et al. 2019). For belowground taxon richness, functional diversity and food-web complexity, standardization was applied within each faunal and microbial group before averaging to counteract overrepresentation of microbial taxa. All ecosystem properties were weighted equally for multifunctionality calculations. Potential collinearity between all pairs of individual ecosystem properties was assessed using Pearson correlations to ensure that no highly correlated variables $(r>1$ $0.71)$ were included, and that no opposing performance (i.e., strong negative correlations) among the individual ecosystem properties was present (Dormann et al. 2013; Appendix S1: Fig. S1).

Treatment differences (explanatory variable) in multifunctionality measures and the 13 ecosystem properties (dependent variables) were assessed using beta regression on standardized values (Ferrari and Cribari-Neto 2004). As beta regression models do only allow for values between 0 and 1 but not both extremes (relevant only for individual properties), we transformed our data accordingly (Smithson and Verkuilen 2006). Significant differences between treatments were identified using likelihood ratio tests (lrtest function of the lmtest $\mathrm{R}$ package, Zeileis and Hothorn 2002). Post hoc pairwise comparisons were adjusted for multiple testing using the Bonferroni correction method in combination with the 
false-discovery-rate approach (cld function of the multcomp R package; Hothorn et al. 2008).

\section{Most cost-effective ways to describe multifunctionality (Research question 4)}

We assessed which ecosystem property or which combination of ecosystem properties explained the highest amount of ecosystem multifunctionality at the lowest possible costs. For this purpose, we calculated 8,190 alternative models using linear regression as implemented in an exhaustive search approach (regsubsets function of the leaps R package; Lumley 2020). These models contained all possible combinations of 13 ecosystem properties, hence we obtained a series of models that included 12 properties (all in EMF.12), a series of models that included 11 properties (EMF.11), and so forth. In a first step, we compared how much variation of ecosystem multifunctionality each of these alternative models explained, using the Bayesian information criterion $(\Delta \mathrm{BIC}>2$, Table 1; Kassambra 2018). We then selected the best models with $12,11,10$, etc. variables.

We estimated costs to each ecosystem property by approximating costs for effort, infrastructure, and expert knowledge that are necessary to collect each of our 13 ecosystem properties (Appendix S1: Tables S4-S7). Costs were classified into coarse categories, represented by pluses $(+)$ and where higher costs equated to more + . We then assigned these costs to each alternative model described above by summing the costs of all ecosystem properties included in the respective models. We selected the models with $12,11,10$, etc. variables with the lowest costs (Table 2). Thus, we were able to evaluate how much an alternative model explained and how much it would roughly cost to collect the data contained in it. A complete list of all alternative models calculated is shown in Data S1: List S1.

All statistical analyses and graphical outputs were performed in $\mathrm{R}$ version 3.6.0 ( $\mathrm{R}$ Core Team 2019). A full list of all packages used can be found in Appendix S1: Table S8.

\section{RESUlTS}

Ecosystem multifunctionality was higher in all three restored treatments than in Initial, but only Topsoil and Topsoil + Propagules reached Target levels (Fig. 1a). Treatment differences in ecosystem multifunctionality were mainly associated to differences in aboveground (Fig. 1b) and biotic (Fig. 1d) multifunctionality, with the two topsoil removal treatments reaching higher levels than Harvest only. Interestingly, the two topsoil removal treatments resulted in even higher aboveground and biotic multifunctionality than Target (Fig. 1b, d). Belowground (Fig. 1c) as well as abiotic (Fig. 1e) multifunctionality did not differ among the three restoration methods, but were significantly higher than in Initial and significantly lower than in Target (exception: belowground multifunctionality in Topsoil). Aboveground, belowground, biotic and abiotic multifunctionality were positively correlated with ecosystem multifunctionality (Appendix S1: Figs. S2a-d).

Seven out of the 13 ecosystem properties contributed significantly to both explaining ecosystem multifunctionality and discriminating among the five treatments: plant species richness, vegetation structure, soil heterogeneity, belowground functional diversity, aboveground food-web complexity, soil $\mathrm{C}$ storage, and soil net $\mathrm{N}$ mineralization (Fig. 2, Table 1).

Including more variables into our model explained more variation in ecosystem multifunctionality. Yet, naturally, this also increases the costs of collecting the data. The model including all 13 ecosystem properties equals $100 \%$ ecosystem multifunctionality and would cost the most $(77+)$. Interestingly, we found negative relationships between explained variation in ecosystem multifunctionality and costs for each group of models that included the same number of variables (Fig. 3). This means that low-cost measures explained relatively more variation of ecosystem multifunctionality compared to high-cost measures within a model cluster (Fig. 3, Table 1 and 2). Models with two or more properties included were able to explain $\geq 70 \%$ of ecosystem multifunctionality, however, the costs were $10+$ and up (Table 2). The "cheapest" model was based on vegetation structure $(1+)$, but explained only $48.8 \%$ of ecosystem multifunctionality (Table 1). Plant species richness accounted for $53.5 \%$ of ecosystem multifunctionality at roughly $4 \%(3+)$ of the cost of the model including all 13 properties $(77+)$ and represented the best individual indicator of all 13 ecosystem properties (Table 1). Plant species richness, in addition, discriminated significantly among the treatments (Fig. 2, Table 1).

Vegetation structure, soil $\mathrm{C}$ storage, and water-holding capacity together explained $70.1 \%$ of ecosystem multifunctionality at the costs of roughly $8 \%(6+)$ of what it took to obtain all 13 variables. On the contrary, by using vegetation structure, soil $\mathrm{C}$ storage, and water-holding capacity, we increased the costs by roughly $17 \%$ compared to when we only used vegetation structure alone, but we gained $21.3 \%$ of explained variation of ecosystem multifunctionality (Table 1). Hence, this model can be considered the most cost effective while describing a high amount of ecosystem multifunctionality (Table 2).

\section{Discussion}

\section{Restoring grassland multifunctionality}

Ecosystem multifunctionality was significantly higher in seminatural grasslands compared to intensively managed grasslands (research question 1). This is in line with studies showing that intensive agriculture decreases multifunctionality by homogenizing plant and faunal communities and soil properties (e.g., Birkhofer et al. 2012, Gossner et al. 2016, Soliveres et al. 2016), and reducing functional diversity at local and landscape scales (Allan 
TABLE 1. Statistical analyses for all 13 ecosystem properties that we used to calculate ecosystem multifunctionality, and to discriminate among our restored, intensively managed and seminatural grasslands (overall, pairwise comparison).

\begin{tabular}{|c|c|c|c|c|c|c|c|c|c|c|c|c|c|c|}
\hline \multicolumn{5}{|c|}{ Ecosystem property } & \multicolumn{5}{|c|}{ Ecosystem multifunctionality } & \multicolumn{5}{|c|}{ Treatment } \\
\hline No. & Name & Cost & $r^{2}$ & $\chi^{2}$ & $P$ & $\mathrm{BIC}$ & $\Delta \mathrm{BIC}$ & $\chi^{2}$ & $P$ & I & $\mathrm{H}$ & Ts & TsP & $\mathrm{T}$ \\
\hline \multicolumn{15}{|c|}{ Biodiversity } \\
\hline 1 & $\begin{array}{l}\text { Arthropod } \\
\text { richness AG }\end{array}$ & $7+$ & 0.351 & 23.657 & $<0.001$ & -15.7 & 18.4 & 7.504 & 0.112 & $\mathrm{a}$ & a & a & a & a \\
\hline 2 & Taxon richness BG & $9+$ & 0.001 & 0.034 & 0.853 & 8.0 & 42.1 & 3.174 & 0.529 & $\mathrm{a}$ & $\mathrm{a}$ & $\mathrm{a}$ & $\mathrm{a}$ & $\mathrm{a}$ \\
\hline 3 & Plant species richness & $3+$ & 0.535 & 42.380 & $<0.001$ & -34.1 & - & 63.530 & $<0.001$ & $\mathrm{c}$ & $\mathrm{b}$ & $\mathrm{a}$ & $\mathrm{a}$ & a \\
\hline \multicolumn{15}{|c|}{$\begin{array}{c}\text { Structural } \\
\text { diversity }\end{array}$} \\
\hline 4 & Vegetation structure & $1+$ & 0.488 & 36.012 & $<0.001$ & -28.8 & 5.3 & 34.128 & $<0.001$ & $\mathrm{c}$ & $\mathrm{c}$ & $\mathrm{b}$ & $\mathrm{a}$ & $\mathrm{b}$ \\
\hline 5 & Soil heterogeneity & $8+$ & 0.074 & 4.045 & 0.044 & 3.8 & 37.9 & 9.786 & 0.044 & $a b$ & $\mathrm{~b}$ & $\mathrm{ab}$ & $a b$ & $\mathrm{a}$ \\
\hline 6 & $\begin{array}{l}\text { Functional } \\
\text { diversity AG }\end{array}$ & $8+$ & 0.005 & 0.227 & 0.634 & 7.8 & 41.9 & 15.554 & 0.004 & $a b$ & $\mathrm{~b}$ & $\mathrm{~b}$ & $\mathrm{a}$ & $\mathrm{b}$ \\
\hline 7 & $\begin{array}{l}\text { Functional } \\
\text { diversity BG }\end{array}$ & $10+$ & 0.138 & 8.140 & 0.004 & -0.2 & 34.0 & 17.196 & 0.002 & $\mathrm{~b}$ & $\mathrm{~b}$ & $\mathrm{a}$ & $\mathrm{b}$ & $\mathrm{b}$ \\
\hline 8 & $\begin{array}{l}\text { Food-web } \\
\text { complexity AG }\end{array}$ & $8+$ & 0.323 & 21.404 & $<0.001$ & -13.4 & 20.7 & 24.769 & $<0.001$ & $\mathrm{c}$ & $\mathrm{bc}$ & $\mathrm{b}$ & $\mathrm{a}$ & $\mathrm{bc}$ \\
\hline 9 & $\begin{array}{l}\text { Food-web } \\
\text { complexity BG }\end{array}$ & $10+$ & 0.015 & 0.861 & 0.354 & 7.2 & 41.3 & 4.790 & 0.310 & $\mathrm{a}$ & $\mathrm{a}$ & a & $\mathrm{a}$ & $\mathrm{a}$ \\
\hline \multicolumn{15}{|c|}{$\begin{array}{l}\text { Soil } \\
\text { functions }\end{array}$} \\
\hline 10 & Soil C storage & $2+$ & 0.140 & 8.802 & 0.003 & -0.3 & 33.8 & 15.126 & 0.004 & $\mathrm{c}$ & $a b$ & $\mathrm{ab}$ & $\mathrm{bc}$ & a \\
\hline 11 & $\begin{array}{l}\text { Water-holding } \\
\text { capacity }\end{array}$ & $3+$ & 0.209 & 12.999 & $<0.001$ & -4.9 & 29.2 & 8.798 & 0.066 & $\mathrm{a}$ & $\mathrm{a}$ & $\mathrm{a}$ & $\mathrm{a}$ & $\mathrm{a}$ \\
\hline 12 & $\begin{array}{l}\text { Nutrient retention } \\
\text { capacity }\end{array}$ & $3+$ & 0.179 & 11.416 & $<0.001$ & -2.9 & 31.3 & 9.245 & 0.055 & $\mathrm{a}$ & $\mathrm{a}$ & $\mathrm{a}$ & $\mathrm{a}$ & $\mathrm{a}$ \\
\hline \multicolumn{15}{|c|}{$\begin{array}{l}\text { Soil } \\
\text { process }\end{array}$} \\
\hline 13 & $\begin{array}{l}\text { Soil net } \\
\mathrm{N} \text { mineralization }\end{array}$ & $5+$ & 0.420 & 29.864 & $<0.001$ & -21.9 & 12.2 & 49.884 & $<0.001$ & $\mathrm{~d}$ & $\mathrm{c}$ & $\mathrm{b}$ & $\mathrm{b}$ & $\mathrm{a}$ \\
\hline
\end{tabular}

Notes: Model comparison was based on the explained variation of ecosystem multifunctionality $\left(r^{2}\right)$ and on the Bayesian information criterion (BIC). Ecosystem properties are sorted by ecosystem attribute and consecutively numbered (No.). Cost is cost categorization according to effort, infrastructure, and expert knowledge needed for assessment (see Appendix S1: Table S4); $r^{2}$, pseudo $r^{2} ; \chi^{2}$, chi squared value; $\Delta$ BIC, difference in BIC units to the lowest ranked property (lowest BIC is plant species richness); I, Initial; H, Harvest only; Ts, Topsoil; TsP, Topsoil + Propagules; T, Target; AG, aboveground; BG, belowground. Different lowercase letters indicate significant differences between treatments. Bold numbers indicate significance at $5 \%$ level.

et al. 2015, Neff et al. 2019). In contrast, traditionally managed seminatural grasslands are characterized by high taxonomic and structural heterogeneity above- and belowground (Lachat et al. 2010, Diacon-Bolli et al. 2012, Byrne and delBarco-Trillo 2019, Peciña et al. 2019), thereby supporting multiple functions and services simultaneously.

For all three restoration methods, we found higher ecosystem multifunctionality than in intensively managed grasslands, but only the two topsoil removal treatments reached Target levels within $22 \mathrm{yr}$ (research question 2). Thus, these restoration methods allow rebuilding multifunctionality comparable to the targeted seminatural grasslands over decadal time frames, which has already been reported from peatlands (Strobl et al. 2019). We also provide strong evidence that topsoil removal not only promoted the restoration of grassland multifunctionality, but also successfully reestablished ecosystem multifunctionality comparable to the targeted seminatural grasslands. Similar results have been reported for Mediterranean forests, where the long-term recovery of forest multifunctionality depended on the intervention intensity of the restoration methods used (natural regeneration vs. active planting; Cruz-Alonso et al. 2019).

We assessed 13 different biotic and abiotic, above- and belowground ecosystem properties that represented key attributes of the targeted ecosystem. We specifically focused on integrating belowground ecosystem properties and functions as their recovery during restoration has been suggested essential for evaluation (see Bardgett et al. 2005, Meyer et al. 2015), especially for restoration methods that strongly affect the soil, such as topsoil removal. This comprehensive assessment allowed us to also identify the contribution of the different ecosystem components to multifunctionality of restored grasslands (research question 3). Thereby, we demonstrated that topsoil removal clearly accelerated the recovery of biotic and aboveground multifunctionality while it had no negative long-term effects on abiotic or belowground multifunctionality compared to low intervention methods. Topsoil removal even led to a higher biotic multifunctionality compared to the Target, indicating that our measures succeeded in creating species-rich and 
TABLE 2. Comparison of top alternative models based on highest explained variation of ecosystem multifunctionality (EMF) or lowest cost.

\begin{tabular}{|c|c|c|c|c|c|c|}
\hline \multirow[b]{2}{*}{$\begin{array}{l}\text { EMF } \\
\text { model }\end{array}$} & \multicolumn{3}{|r|}{ Highest explanatory power } & \multicolumn{3}{|r|}{ Lowest cost } \\
\hline & $\begin{array}{l}\text { EMF } \\
(\%)\end{array}$ & Cost & Properties considered & $\begin{array}{c}\text { EMF } \\
(\%)\end{array}$ & Cost & Properties considered \\
\hline EMF.12 & 99.5 & $67+$ & $1+2+3+4+5+6+7+8+10+11+12+13$ & 99.5 & $67+$ & $1+2+3+4+5+6+7+8+10+11+12+13$ \\
\hline EMF.11 & 98.8 & $58+$ & $1+3+4+5+6+7+8+10+11+12+13$ & 97.5 & $57+$ & $1+2+3+4+5+6+8+10+11+12+13$ \\
\hline EMF.10 & 98.1 & $55+$ & $1+3+4+5+6+7+8+10+11+13$ & 97.2 & $48+$ & $1+3+4+5+6+8+10+11+12+13$ \\
\hline EMF.9 & 97.2 & $50+$ & $1+3+4+5+6+7+8+10+11$ & 96.2 & $40+$ & $1+3+4+5+8+10+11+12+13$ \\
\hline EMF.8 & 96.3 & $42+$ & $1+3+4+5+7+8+10+11$ & 92.5 & $32+$ & $1+3+4+8+10+11+12+13$ \\
\hline EMF.7 & 95.4 & $36+$ & $1+3+5+8+10+11+13$ & 85.6 & $24+$ & $1+3+4+10+11+12+13$ \\
\hline EMF.6 & 94.4 & $31+$ & $1+3+5+8+10+11$ & 80.2 & $17+$ & $3+4+10+11+12+13$ \\
\hline EMF.5 & 89.8 & $23+$ & $1+3+8+10+11$ & 78.3 & $12+$ & $3+4+10+11+12$ \\
\hline EMF.4 & 87.5 & $21+$ & $1+3+8+11$ & 77.9 & $9+$ & $3+4+10+11$ \\
\hline EMF.3 & 80.4 & $14+$ & $3+8+11$ & 70.1 & $6+$ & $4+10+11$ \\
\hline EMF.2 & 70.8 & $10+$ & $1+3$ & 57.8 & $3+$ & $4+10$ \\
\hline EMF.1 & 53.5 & $3+$ & 3 & 48.8 & $1+$ & 4 \\
\hline
\end{tabular}

Notes: Alternative ecosystem multifunctionality models were clustered according to the number of ecosystem properties included in the calculations (EMF.1-12). Alternative models for highest explanatory power were compared based on the Bayesian information criteria (BIC) and considered different when the difference in $\triangle \mathrm{BIC}$ was $>2$ (Kassambra 2018; Data S1: List S1). This was done for each cluster separately. EMF (\%) is the percentage of ecosystem multifunctionality explained; Cost is total costs for a specific model (Table 1; Appendix S1: Table S4; Data S1: List S1); Properties considered is the list of ecosystem properties included, numbers correspond to Table 1 (No.).
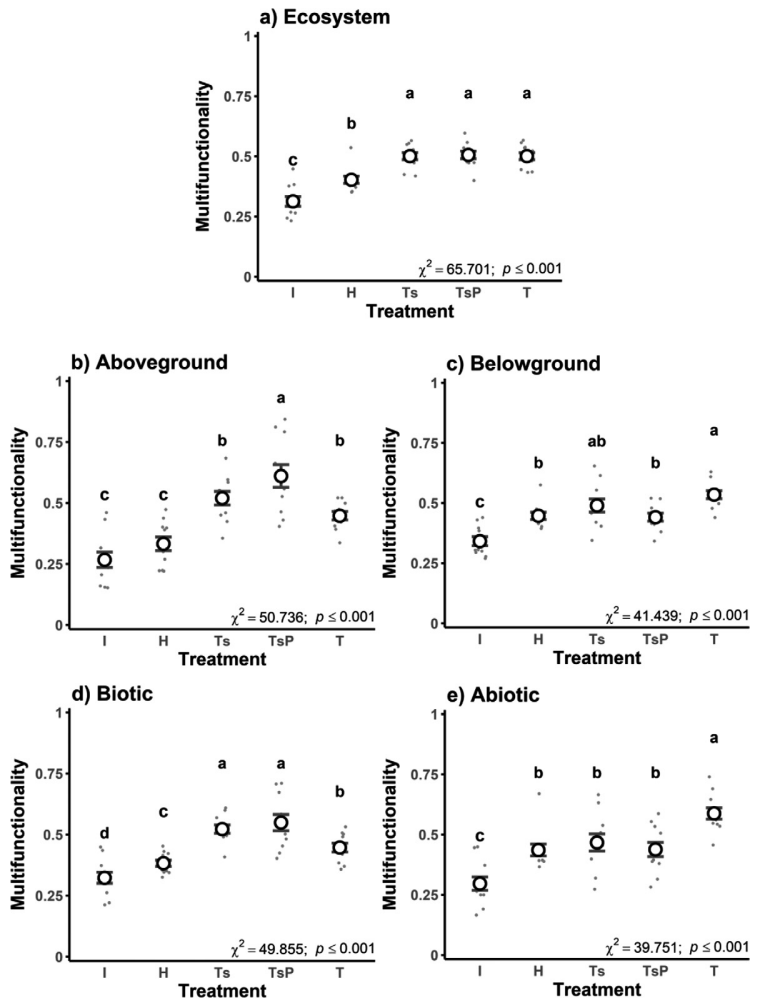

FIG. 1. Treatment effects on (a) ecosystem, (b) aboveground, (c) belowground, (d) biotic, and (e) abiotic multifunctionality (including mean $\pm \mathrm{SE}$ ). All five multifunctionality measures represent weighted average values of standardized properties ( $y$-axis: scaled between 0 and 1). I, Initial; H, Harvest only; Ts, Topsoil; TsP, Topsoil + Propagules; T, Target. Different lowercase letters indicate significant differences between treatments. functional systems, which are, however, slightly different from our Target sites. Furthermore, our results also revealed that abiotic multifunctionality in all three restoration methods did not reach target levels, even $22 \mathrm{yr}$ after treatment implementation. Thus, the longterm recovery of abiotic soil properties lags behind aboveground properties. This is in line with short-term studies reporting time lags in the response of biotic aboveground and belowground communities to changed soil conditions (see Bardgett et al. 2005, Kardol et al. 2005, 2009a). The apparent failure in recreating soils with an equivalent level of abiotic multifunctionality compared to target systems, therefore, underlines that protection and conservation efforts are most urgently needed to minimize degradation and loss of biodiversity and ecosystem functioning (e.g., United Nations 2015: Sustainable Development Goal 15, Pe'er et al. 2020).

Although particular standards for ecological restoration urged the need for comprehensive assessments (see Gann et al. 2019), long-term multifunctionality studies in grassland ecosystems have so far been lacking. In addition, studies assessing the long-term recovery of multiple biotic and abiotic belowground properties after topsoil removal are scarce and primarily focused on individual properties (e.g., Frouz et al. 2009, Wubs et al. 2016, Resch et al. 2019). Here, we show that long-term studies that incorporate multiple above- and belowground ecosystem components are important as the evaluation of restoration success strongly depends on the number and identity of the indicators used (e.g., Montoya et al. 2012, Wortley et al. 2013). Thus, we strongly recommend integrating biotic and abiotic, above- and belowground properties in long-term 

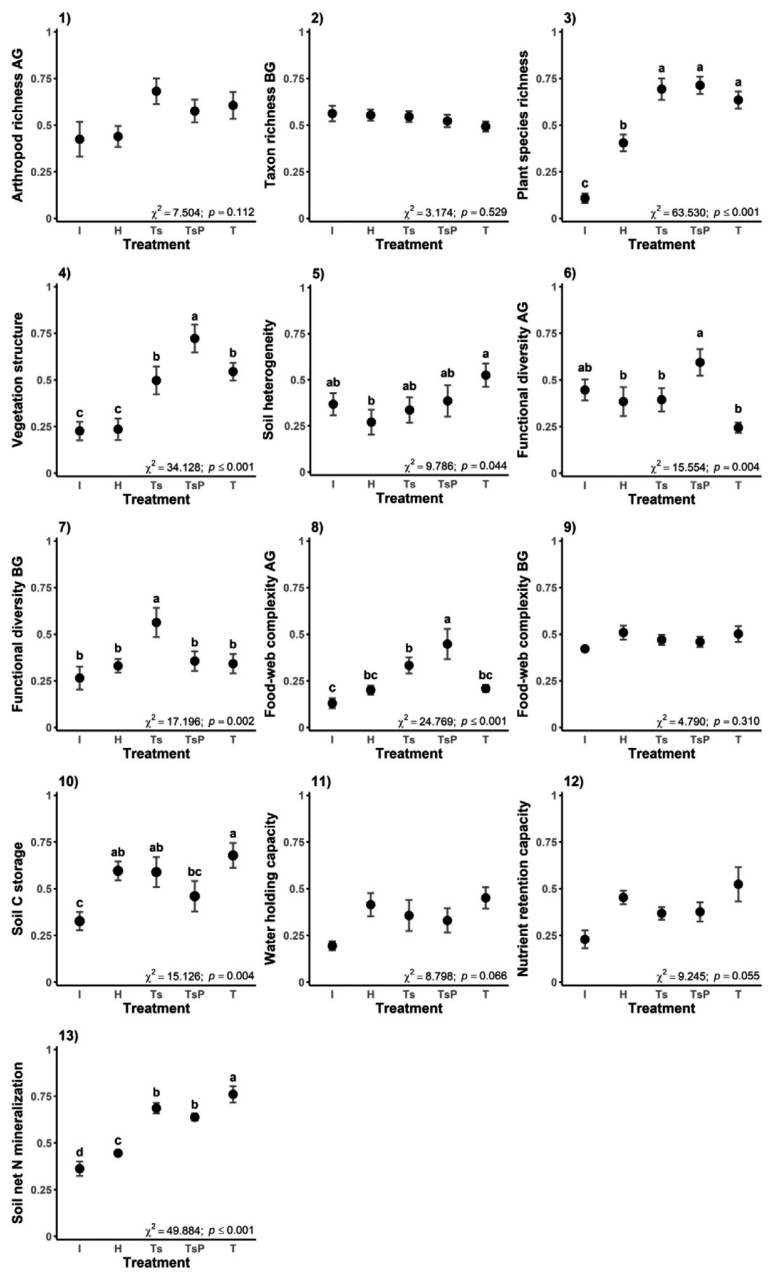

FIG. 2. Treatment effects on standardized ecosystem properties (mean \pm SE; 1-13, see Table 1). AG, aboveground; BG, belowground; I, Initial; H, Harvest only; Ts, Topsoil; TsP, Topsoil + Propagules; T, Target. Different lowercase letters indicate significant differences between treatments.

monitoring programs to appropriately represent the entire ecosystem.

\section{Revealing ecosystem multifunctionality in a most cost- efficient way}

We used 13 ecosystem properties to calculate ecosystem multifunctionality, which was highly resource-intensive. Monitoring the success of restoration projects is normally resource limited, only allowing for the collection of a restricted set of properties (Montoya et al. 2012, Gann et al. 2019). To explore which of our 13 properties (alone or in combination) would be best suited to describe ecosystem multifunctionality with relative high accuracy, but at low costs, we conducted a "cost-benefit analysis" (research question 4). Plant species richness was found to be the most accurate individual indicator successfully describing ecosystem multifunctionality $(53.5 \%)$, which supports its supremacy as the most commonly used biotic indicator for conservation agencies conducting such restoration monitoring (Kiehl et al. 2010). Vegetation structure would be the cheapest individual property, but still described quite a high amount of ecosystem multifunctionality $(48.8 \%)$, hence, could be used instead of plant species richness if funding is limited or experts are scarce, but long-term restoration monitoring is stipulated by statutory regulations. However, vegetation structure complemented with two low-cost belowground properties, i.e., soil $\mathrm{C}$ storage and water-holding capacity, would allow for a highly cost-effective monitoring of ecosystem multifunctionality. Such a combination provides land managers or nature protection agencies with an accurate measure to monitor how ecosystem multifunctionality is restored over decadal time frames.

\section{Conclusions}

Long-term monitoring of restoration projects is indispensable to implement adaptive management strategies if necessary and assess restoration success. This is of 


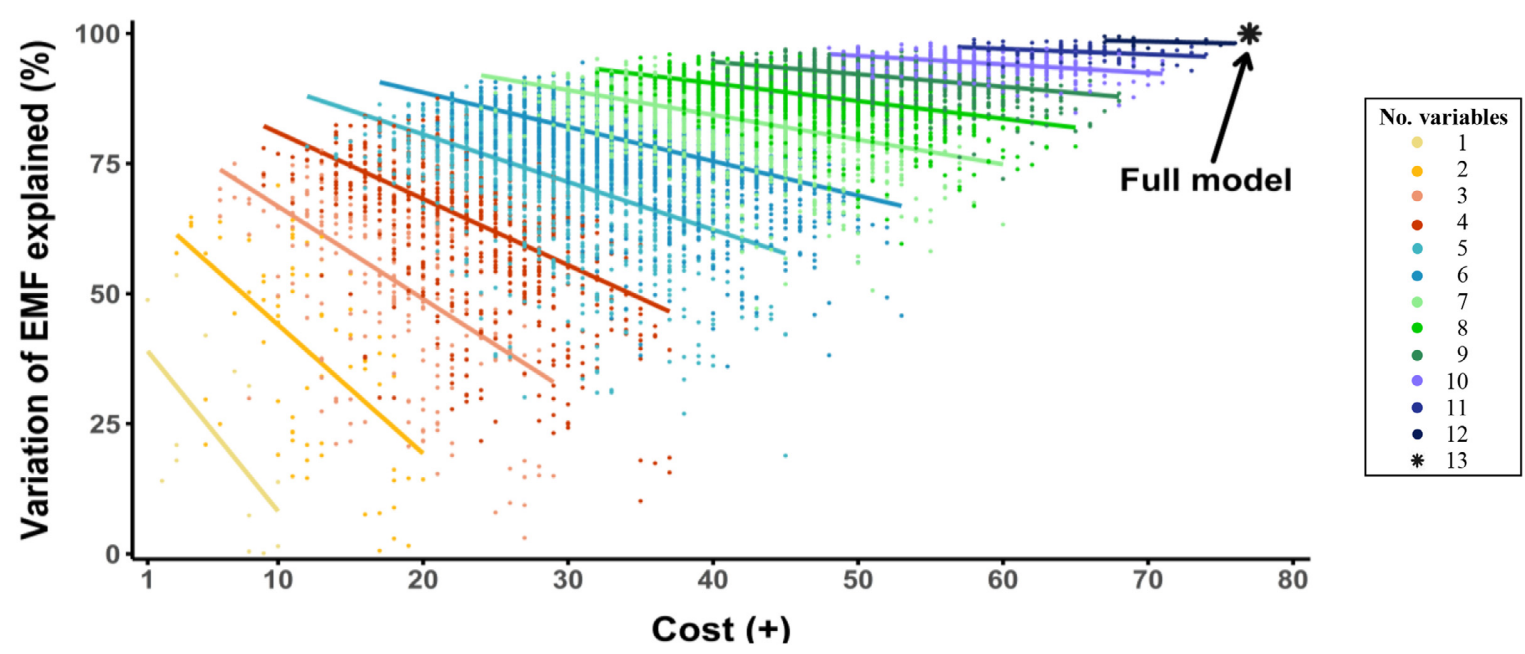

FIG. 3. Relationship of explained variation of ecosystem multifunctionality (EMF) with costs for individual and multiple ecosystem properties. Subsets of possible combinations were identified by the stepwise reduction of all 13 ecosystem properties using an exhaustive search approach, which resulted in 8,190 alternative calculations of ecosystem multifunctionality (single points; Data S1: List S1). Alternative calculations of ecosystem multifunctionality were clustered by number of included ecosystem properties (No. variables) and indicated by different colors. Linear regressions were calculated per cluster and also indicated in the respective colors. For comparison, ecosystem multifunctionality calculated based on all 13 properties and the respective costs are also shown († full model).

major importance for industries (e.g., mining companies), governments, communities, and land managers ultimately responsible for implementing enforced statutory regulations and the subsequent evaluation of restoration activities in the long term. Practical standards to monitor and evaluate restoration have already been proposed. Nevertheless, long-term studies combining aboveground and belowground ecosystem multifunctionality assessments to evaluate the recovery of targeted ecosystem properties were lacking. Therefore, the findings of our study can serve as a guideline to monitor and evaluate long-term grassland restoration, using a comprehensive, multifunctional approach.

In the advent of the United Nations Decade on Ecosystem Restoration (2021-2030) multiple priorities need to be set to foster the cumulative gains of restoration actions across the globe. Hence, new restoration initiatives should not only focus on defining which specific types of ecosystems or global regions should be prioritized for restoration activities, but also on promoting and implementing cost-efficient properties to accurately assess entire ecosystems and their recovery following restoration. In this study, we showed that for our grassland systems assessing vegetation structure, soil C storage, and water-holding capacity allows for a highly costeffective long-term monitoring of ecosystem multifunctionality. As this is one of the first studies considering a multifunctionality approach, further evidence from other ecosystems is needed to validate the generality of our results. Nevertheless, we are highly confident that our findings can serve as a baseline to help overcome funding limitations within restoration projects, often prevalent in less developed countries where restoration activities are especially needed.

\section{ACKNOWLedgments}

We thank Matthias Diener, Njoku Nwawudu, Anja Marty, and Martin Gossner for help in sampling and sorting of invertebrates as well as laboratory work on soil properties; Benjamin Fitzpatrick for suggestions regarding statistical methods; the Genetic Diversity Centre (GDC) of ETH Zurich for suggestions regarding analyzing molecular data; and Roel Wagenaar, Roger Köchli, Daniel Christen, Marco Walser, and Beat Stierli for technical assistance. We also thank the Nature Conservation Agency of Canton Zurich, under the supervision of Pascale Weber and Ursina Wiedmer, for administrative support with farmers, regional commissioners for nature conservation and access permits for the respective nature reserves. This work was supported by the Swiss National Science Foundation (grant number 31003A_166654). Authors' contributions: MCR, ACR, MS, BF, SZ, and NB designed the experiment; MCR, ACR, and MS developed the ideas for the manuscript; MCR, SZ, and UG collected the data; WHvdP, BF, and SZ, led the lab work; MCR analyzed the data and wrote the first draft of the paper; ACR and MS commented on all drafts of the paper; $\mathrm{NB}, \mathrm{BF}, \mathrm{UG}, \mathrm{SZ}$, and $\mathrm{WHvdP}$ contributed critically to the advanced drafts of the paper; all authors gave final approval for publication.

\section{Literature Cited}

Adamczyk, M., F. Hagedorn, S. Wipf, J. Donhauser, P. Vittoz, C. Rixen, A. Frossard, J. Theurillat, and B. Frey. 2019. The soil microbiome of GLORIA mountain summits in the Swiss Alps. Frontiers in Microbiology 10:1080-1101.

Allan, E., et al. 2015. Land use intensification alters ecosystem multifunctionality via loss of biodiversity and changes to functional composition. Ecology Letters 18:834-843. 
Alsterberg, C., F. Roger, K. Sundbäck, J. Juhanson, S. Hulth, S Hallin, and L. Gamfeldt. 2017. Habitat diversity and ecosystem multifunctionality-The importance of direct and indirect effects. Science Advances 3:e1601475.

Bakker, J. P., and F. Berendse. 1999. Constraints in the restoration of ecological diversity in grassland and heathland communities. Trends in Ecology and Evolution 14:63-68.

Bardgett, R. D., W. D. Bowmann, R. Kaufmann, and S. K. Schmitdt. 2005. A temporal approach to linking aboveground and belowground ecology. Trends in Ecology and Evolution 20:634-641.

Birkhofer, K., et al. 2012. General relationships between abiotic soil properties and soil biota across spatial scales and different land-use types. PLoS ONE 7:e43292.

Blake, G. R., and K. H. Hartge. 1986. Particle Density. Pages 377-382 in A. Klute, editor. Methods of soil analysis: Part 1-Physical and mineralogical methods. Soil Science Society of America (SSSA), Madison, Wisconsin, USA.

Bobbink, R., S. Braun, A. Nordin, S. Power, K. Schütz, J. Strengbom, M. Weijters, and H. Tomassen. 2011. Effects of nitrogen inputs in grasslands and lands dominated by forbs, mosses and lichens (EUNIS class E). Pages 87-106 in R. Bobbink and J. P. Hettelingh, editors. Review and revision of empirical critical loads and dose-response relationships: Proceedings of an expert workshop. UNECE Coordination Centre for Effects (CCE), Bilthoven, The Netherlands.

Bobbink, R., M. Hornung, and J. G. M. Roelofs. 1998. The effects of air-borne nitrogen pollutants on species diversity in natural and semi-natural European vegetation. Journal of Ecology 86:717-738.

Bongers, T. 1988. De nematoden van Nederland. Stichting Uitgeverij van de Koniklijke Nederlandse Natuurhistorische Verenigung (KNNV), Utrecht, The Netherlands.

Bongers, T. 1990. The maturity index: an ecological measure of environmental disturbance based on nematode species composition. Oecologia 83:14-19.

Bouché, M. B. 1977. Strategies lombriciennes. Ecological Bulletins 25:122-132.

Brinkman, E. P., C. E. Raaijmakers, W. de Boer, and W. H. van der Putten. 2017. Changing soil legacies to direct restoration of plant communities. AoB Plants 9:plx038.

Byrne, F., and J. delBarco-Trillo. 2019. The effect of management practices on bumblebee densities in hedgerow and grassland habitats. Basic and Applied Ecology 35:29-33.

Byrnes, J. E. K., L. Gamfeldt, F. Isbell, J. S. Lefcheck, J. N. Griffin, A. Hector, B. J. Cardinale, D. U. Hooper, L. E. Dee, and J. E. Duffy. 2014. Investigating the relationship between biodiversity and ecosystem multifunctionality: challenges and solutions. Methods in Ecology and Evolution 5:111-124.

Christian, E., and A. Zicsi. 1999. Ein synoptischer Bestimmungsschlüssel der Regenwürmer Österreichs (Oligochaeta: Lumbricidae). Die Bodenkultur 50:121-131.

Costantini, E. A., C. Branquinho, A. Nunes, G. Schwilch, I. Stavi, A. Valdecantos, and C. Zucca. 2016. Soil indicators to assess the effectiveness of restoration strategies in dryland ecosystems. Solid Earth 7:397-414.

Cruz-Alonso, V., P. Ruiz-Benito, P. Villar-Salvador, and J. M. Rey-Benayas. 2019. Long-term recovery of multifunctionality in Mediterranean forests depends on restoration strategy and forest type. Journal of Applied Ecology 56:745-757.

Danielson, R. E., and P. L. Sutherland. 1986. Porosity. Pages 443-461 in A. Klute, editor. Methods of soil analysis: Part 1 -Physical and mineralogical methods. Soil Science Society of America (SSSA), Madison, Wisconsin, USA.

De Deyn, G. B., C. E. Raaijmakers, H. R. Zoomer, M. P. Berg, P. C. de Ruiter, H. A. Verhoef, T. M. Bezemer, and W. H. van der Putten. 2003. Soil invertebrate fauna enhances grassland succession and diversity. Nature 422:711-713.

Delarze, R., Y. Gonseth, S. Eggenberg, and M. Vust 2015. Lebensräume der Schweiz: Ökologie-Gefährdung-Kennarten. Ott Verlag, Bern, Switzerland.

Delgado-Baquerizo, M., et al. 2019. Changes in belowground biodiversity during ecosystem development. Proceedings of the National Academy of Sciences USA 116:6891-6896.

Dengler, J., M. Janisová, P. Török, and C. Wellstein. 2014. Biodiversity of Palaearctic grasslands: a synthesis. Agriculture, Ecosystem and Environment 182:1-14.

Diacon-Bolli, J., T. Dalang, R. Holderegger, and M. Bürgi. 2012. Heterogeneity fosters biodiversity: Linking history and ecology of dry calcareous grasslands. Basic and Applied Ecology 13:641-653.

Dormann, C. F., et al. 2013. Collinearity: a review of methods to deal with it and a simulation study evaluating their performance. Ecography 36:27-46.

Edgar, R. C. 2010. Search and clustering orders of magnitude faster than BLAST. Bioinformatics 26:2460-2461.

Edgar, R. C. 2013. UPARSE: highly accurate OTU sequences from microbial amplicon reads. Nature Methods 10: 996-998.

FAO. 1990. Guidelines for soil description. Third edition. Land and Water Development Division at the Food and Agriculture Organization of the United Nations (FAO), Rome, Italy.

Ferrari, S., and F. Cribari-Neto. 2004. Beta regression for modelling rates and proportions. Journal of Applied Statistics 31:799-815.

Frey, B., T. Rime, M. Phillips, B. Stierli, I. Hajdas, F. Widmer, and M. Hartmann. 2016. Microbial diversity in European alpine permafrost and active layers. FEMS Microbiology Ecology 92:fiw018.

Frouz, J., R. Van Diggelen, V. Pižl, J. Starý, L. Háněl, K. Tajovský, and J. Kalčík. 2009. The effect of topsoil removal in restored heathland on soil fauna, topsoil microstructure, and cellulose decomposition: Implications for ecosystem restoration. Biodiversity and Conservation 18:3963-3978.

Gamfeldt, L., H. Hillebrand, and P. R. Jonsson. 2008. Multiple functions increase the importance of biodiversity for overall ecosystem functioning. Ecology 89:1223-1231.

Gamfeldt, L., and F. Roger. 2017. Revisiting the biodiversity-ecosystem multifunctionality relationship. Nature Ecology and Evolution 1:0168.

Gann, G. D., et al. 2019. International principles and standards for the practice of ecological restoration. Second edition. Restoration Ecology 27:S3-S46.

Gattlen, N., G. Klaus, and G. Litsios. 2017. Biodiversität in der Schweiz: Zustand und Entwicklung. Ergebnisse des Überwachungssystems im Bereich Biodiversität, Stand 2016. Bundesamt für Umwelt, Bern, Switzerland.

Gee, G. W., and J. W. Bauder. 1986. Particle-size analysis. Pages 383-411 in A. Klute, editor. Methods of soil analysis: Part 1 - Physical and mineralogical methods. Soil Science Society of America (SSSA), Madison, Wisconsin, USA.

Geissen, V., S. Wang, K. Oostindie, E. Huerta, K. B. Zwart, A. Smit, C. J. Ritsema, and D. Moore. 2013. Effects of topsoil removal as a nature management technique on soil functions. Catena 101:50-55.

Gimmi, U., T. Lachat, and M. Bürgi. 2011. Reconstructing the collapse of wetland networks in the Swiss lowlands 1850-2000. Landscape Ecology 26:1071-1083.

Gossner, M. M., et al. 2016. Land-use intensification causes multitrophic homogenization of grassland communities. Nature 540:266-269. 
Greiner, L., M. Nussbaum, A. Papritz, M. Fraefel, S. Zimmermann, P. Schwab, A. Gret-Regamey, and A. Keller. 2018. Assessment of soil multi-functionality to support the sustainable use of soil resources on the Swiss Plateau. Geoderma Regional 14:1-15.

Hart, S. C., J. M. Stark, E. A. Davidson, and M. K. Firestone 1994. Nitrogen mineralization, immobilization, and nitrification. Pages 985-1016 in R. W. Weaver, S. Angle, P. Bottomley, D. Bezdicek, S. Smith, A. Tabatabai, and A. Wollum, editors. Methods of soil analysis: Part 2-Microbiological and biochemical properties. Soil Science Society of America (SSSA), Madison, Wisconsin, USA.

Havlicek, E. 2012. Soil biodiversity and bioindication: From complex thinking to simple acting. European Journal of Soil Biology 49:80-84.

Ho, A., D. P. Di Lonardo, and P. L. E. Bodelier. 2017. Revisiting life strategy concepts in environmental microbial ecology. FEMS Microbiology Ecology 93:fix006.

Hooper, D. U., and P. M. Vitousek. 1998. Effects of plant composition and diversity on nutrient cycling. Ecological Monographs 68:121-149.

Hothorn, T., F. Bretz, and P. Westfall. 2008. Simultaneous inference in general parametric models. Biometrical Journal 50:346-363.

Kardol, P., T. M. Bezember, A. van der Wal, and W. H. van der Putten. 2005. Successional trajectories of soil nematode and plant communities in a chronosequence of ex-arable land. Biological Conservation 126:317-327.

Kardol, P., T. M. Bezemer, and W. H. van der Putten. $2009 a$. Soil organisms and plant introduction in restoration of species-rich grassland communities. Restoration Ecology 17:258-269.

Kardol, P., J. S. Newton, T. M. Bezemer, M. Maraun, and W. H. van der Putten. 2009b. Contrasting diversity patterns of soil mites and nematodes in secondary succession. Acta Oecologica 35:603-609.

Kardol, P., A. van der Wal, T. M. Bezemer, W. de Boer, H. Duyts, R. Holtkamp, and W. H. van der Putten. 2008. Restoration of species-rich grasslands on ex-arable land: Seed addition outweighs soil fertility reduction. Biological Conservation 141:2208-2217.

Kardol, P., and D. A. Wardle. 2010. How understanding aboveground-belowground linkages can assist restoration ecology. Trends in Ecology and Evolution 25:670-679.

Kassambra, A. 2018. Model selection: best subsets regression. Pages 77-81 in Machine learning essentials: practical guide in R. Statistical tools for high-throughput data analyses (STHDA). CreateSpace Independent Publishing Platform, Scotts Valley, California, USA.

Kiehl, K., A. Kirmer, T. W. Donath, L. Rasran, and N. Hölzel. 2010. Species introduction in restoration projects-Evaluation of different techniques for the establishment of semi-natural grasslands in Central and Northwestern Europe. Basic and Applied Ecology 11:285-299.

Kiehl, K., and J. Pfadenhauer. 2007. Establishment and persistence of target species in newly created calcareous grasslands on former arable fields. Plant Ecology 189:31-48.

Kiehl, K., and C. Wagner. 2006. Effect of hay transfer on longterm establishment of vegetation and grasshoppers on former arable fields. Restoration Ecology 14:157-166.

Klimkowska, A., R. van Diggelen, J. P. Bakker, and A. P. Grootjans. 2007. Wet meadow restoration in Western Europe: a quantitative assessment of the effectiveness of several techniques. Biological Conservation 140:318-328.

Lachat, T., F. Blaser, R. Bösch, L. Bonnard, U. Gimmi, A. Grünig, C. Roulier, G. Sirena, J. Stöcklin, and G. Volkart. 2010. Verlust wertvoller Lebensräume. Pages 22-63 in T.
Lachat, D. Pauli, Y. Gonseth, G. Klaus, C. Scheidegger, P. Vittoz, and T. Walter, editors. Wandel der Biodiversität in der Schweiz seit 1900: Ist die Tahlsohle erreicht?. Bristol-Stiftung Haupt Verlag, Bern, Switzerland.

Lauber, K., and G. Wagner. 1996. Flora Helvetica. Flora der Schweiz. Haupt Verlag, Bern, Switzerland.

Lumley, T. 2020. leaps: Regression Subset Selection. R package version 3.1. Based on Fortran code by A. Miller. https:// CRAN.R-project.org/package $=$ leaps

Manning, P., F. van der Plas, S. Soliveres, E. Allan, F. T. Maestre, G. Mace, M. J. Whittingham, and M. Fischer. 2018. Redefining ecosystem multifunctionality. Nature Ecology and Evolution 2:427-436.

Marrs, R. H., C. S. R. Snow, K. M. Owen, and C. E. Evans. 1998. Heathland and acid grassland creation on arable soils at Minsmere: identification of potential problems and a test of cropping to impoverish soils. Biological Conservation 85:69-82.

McDonald, T., G. D. Gann, J. Jonson, and K. W. Dixon. 2016. International standards for the practice of ecological restoration-including principles and key concepts. Society for Ecological Restoration, Washington, D.C., USA.

McLauchlan, K. 2006. The nature and longevity of agricultural impacts on soil carbon and nutrients: a review. Ecosystems 9:1364-1382.

MeteoSchweiz 2018. Klimabulletin Jahr 2017. MeteoSchweiz, Zürich, Switzerland.

Meyer, S. T., C. Koch, and W. W. Weisser. 2015. Towards a standardized rapid ecosystem function assessment (REFA). Trends in Ecology and Evolution 30:390-397.

Montoya, D., L. Rogers, and J. Memmott. 2012. Emerging perspectives in the restoration of biodiversity-based ecosystem services. Trends in Ecology and Evolution 27:666-672.

Neff, F., N. Blüthgen, M. N. Chisté, N. K. Simons, J. Steckel, W. W. Weisser, C. Westphal, L. Pellisier, and M. M. Gossner. 2019. Cross-scale effects of land use on the functional composition of herbivorous insect communities. Landscape Ecology 34:2001-2015.

Neff, F., M. C. Resch, A. Marty, J. Rolley, M. Schütz, A. C. Risch, and M. M. Gossner. 2020. Long-term restoration success of insect herbivore communities in semi-natural grasslands-a functional approach. Ecological Applications 30:e02133.

Nguyen, N. H., Z. W. Song, S. T. Bates, S. Branco, L. Tedersoo, J. Menke, J. S. Schilling, and P. G. Kennedy. 2016. FUNGuild: an open annotation tool for parsing fungal community datasets by ecological guild. Fungal Ecology 20:241-248.

Nilsson, R. H., et al. 2018. The UNITE database for molecular identification of fungi: handling dark taxa and parallel taxonomic classifications. Nucleic Acids Research 47:259-264.

Norman, R. J., and J. W. Stucki. 1981. The determination of nitrate and nitrite in soil extracts by ultraviolet spectrophotometry. Soil Science Society of America Journal 45:347-353.

Oksanen, J., et al. 2019. vegan: Community Ecology Package. R package version 2.5-5. https://CRAN.R-project.org/package= vegan

Oostenbrink, M. 1960. Estimating nematode populations by some selected methods. Pages 81-101 in J. J. Sasser and W. R. Jenkins, editors. Nematology. University of North Carolina Press, Chapel Hill, North Carolina, USA.

Parisi, V., C. Menta, C. Gardi, C. Jacomini, and E. Mozzanica. 2005. Microarthropod communities as a tool to assess soil quality and biodiversity: a new approach in Italy. Agriculture, Ecosystems and Environment 105:323-333.

Patzelt, A., U. Wild, and J. Pfadenhauer. 2001. Restoration of wet fen meadows by topsoil removal: vegetation development and germination biology of fen species. Restoration Ecology 9:127-136 
Peciña, M. V., R. D. Ward, R. G. H. Bunce, K. Sepp, V. Kuusemets, and O. Luuk. 2019. Country-scale mapping of ecosystem services provided by semi-natural grasslands. Science of the Total Environment 661:212-225.

Pe'er, G., et al. 2020. Action needed for the EU Common Agricultural Policy to address sustainability challenges. People and Nature 2:305-316.

Poschlod, P., and M. F. Wallis De Vries. 2002. The historical and socioeconomic perspective of calcareous grasslands-lessons from the distant and recent past. Biological Conservation 104:361-376.

Quast, C., E. Pruesse, P. Yilmaz, J. Gerken, T. Schweer, P. Yarza, J. Peplies, and F. O. Glöckner. 2013. The SILVA ribosomal RNA gene database project: improved data processing and web-based tools. Nucleic Acids Research 41:590-596.

Quétier, F., A. Thébault, and S. Lavorel. 2007. Plant traits in a state and transition framework as markers of ecosystem response to land-use change. Ecological Monographs 77:33-52.

R Core Team 2019. R: A language and environment for statistical computing. R Foundation for Statistical Computing, Vienna, Austria.

Resch, M. C., M. Schütz, N. Buchmann, B. Frey, U. Graf, W. H. van der Puten, S. Zimmermann, and A. C. Risch. 2020 Restoring grassland multifunctionality. EnviDat. https://doi. org/10.16904/envidat.169

Resch, M. C., M. Schütz, U. Graf, R. Wagenaar, W. H. van der Putten, and A. C. Risch. 2019. Does topsoil removal in grassland restoration benefit both soil nematode and plant communities? Journal of Applied Ecology 56:1782-1793.

Römbke, J., S. Jänsch, and W. Bidden. 2005. The use of earthworms in ecological soil classification and assessment concepts. Ecotoxicology and Environmental Safety 62:249-265.

Schuldt, A., et al. 2019. Multiple plant diversity components drive consumer communities across ecosystems. Nature Communications 10:1460.

Smithson, M., and J. Verkuilen. 2006. A better lemon squeezer? Maximum-likelihood regression with beta-distributed dependent variables. Psychological Methods 11:54-71.

Soliveres, S., et al. 2016. Locally rare species influence grassland ecosystem multifunctionality. Philosophical Transactions of the Royal Society B 371:20150269.

Strobl, K., J. Kollmann, and L. H. Teixeira. 2019. Integrated assessment of ecosystem recovery using a multifunctional approach. Ecosphere 10:e02930.

Suding, K. N. 2011. Toward an era of restoration in ecology: successes, failures, and opportunities ahead. Annual Review of Ecology, Evolution, and Systematics 42:465-487.

Tedersoo, L., et al. 2014. Global diversity and geography of soil fungi. Science 346:1256688.
Thomas, G. W. 1982. Exchangeable cations. Pages 159-165 in A. L. Page, R. H. Miller, and D. R. Keeney, editors. Methods of soil analysis: part 2-chemical and microbiological properties. Soil Science Society of America (SSSA), Madison, Wisconsin, USA.

Török, P., and J. Dengler. 2018. Palaeartic grasslands in transition: overarching patterns and future prospects. Pages 15-26 in V. R. Squires, J. Dengler, H. Feng, and L. Hua, editors. Grassland of the world: diversity, management and conservation. CRC Press, Boca Raton, Florida, USA.

United Nations 2015. Sustainable development goal 15: Protect, restore and promote sustainable use of terrestrial ecosystems, sustainably manage forests, combat desertification, and halt and reverse land degradation and halt biodiversity loss. Page 27inUnited Nations, editors. Transforming our world: the 2030 agenda for sustainable development. A/RES/70/1. United Nations, New York, New York, USA.

Van Dijk, G. 1991. The status of semi-natural grasslands in Europe. Pages 15-36 in P. D. Goriup, L. A. Batten, and J. A. Norton, editors. The conservation of lowland dry grassland birds in Europe. The Joint Nature Conservation Committee (JNCC), Peterborough, UK

Verhagen, R., R. van Diggelen, and R. Vermeulen. 2008. Community assemblage of the Carabidae fauna in newly created habitats. Baltic Journal of Coleopterology 8: $135-148$.

Wallis De Vries, M. F., R. Poschlod, and J. H. Willems. 2002. Challenges for the conservation of calcareous grasslands in northwestern Europe: integrating the requirements of flora and fauna. Biological Conservation 104:265-273.

Walthert, L., U. Graf, A. Kammer, J. Luster, D. Pezzotta, S. Zimmermann, and F. Hagedorn. 2010. Determination of organic and inorganic carbon, $\delta 13 \mathrm{C}$, and nitrogen in soils containing carbonates after acid fumigation with $\mathrm{HCl}$. Journal of Plant Nutrition and Soil Sciences 173: 207-216.

Wortley, L., J. M. Hero, and M. Howes. 2013. Evaluating ecological restoration success: a review of the literature. Restoration Ecology 21:537-543.

Wubs, E. R. J., W. H. van der Putten, M. Bosch, and T. M. Bezemer. 2016. Soil inoculation steers restoration of terrestrial ecosystems. Nature Plants 2:16107.

Yeates, G. W., T. Bongers, R. G. M. de Goede, D. W. Freckman, and S. S. Georgieva. 1993. Feeding habits in soil nematode families and genera - an outline for soil ecologists. Journal of Nematology 25:315-331.

Zeileis, A., and T. Hothorn. 2002. Diagnostic checking in regression relationships. $\mathrm{R}$ News 2:7-10.

\section{SUPPORTING INFORMATION}

Additional supporting information may be found online at: http://onlinelibrary.wiley.com/doi/10.1002/eap.2271/full

\section{Data Availability}

Data available via the EnviDat Repository (Resch et al. 2020): https://doi.org/10.16904/envidat.169. Raw sequences of the soil microbial community are deposited in the NCBI Sequence Read Archive under the BioProject accession number PRJNA630536. 